\title{
Ssciendo
}

Ethics \& Bioethics (in Central Europe), 2019, 9 (3-4), 106-118

DOI:10.2478/ebce-2019-0017

\section{The literary works as a code of ethics in Great Moravia}

\author{
Vasil Gluchman ${ }^{1}$
}

\begin{abstract}
The author studies selected fundamental literary records from Great Moravia of the $9^{\text {th }}$ century (The rules of the holy fathers [Zapovědi svatych otcov], Judicial law for laymen [Zakon sudnyj ljudem], Nomocanon [Nomokanon], Adhortation to rulers [Vladykam zemle Božie slovo velit]) presumably compiled, translated or created by Constantine (Cyril) and Methodius, the Thessaloniki brothers. In the context of defining early and medieval Christian ethics, the author concluded that the texts in question contain elements of the Christian code of ethics, by means of which Constantine (Cyril) and Methodius, following the model of the Byzantine Emperors Leo III and Constantine V, wished to form the social morality of Great Moravia. Based on this, the author holds the opinion that the history of Christian ethics in Moravia, Slovakia and Bohemia goes as far back as the activities of Constantine (Cyril) and Methodius and the period of Great Moravia.
\end{abstract}

Keywords: Constantine (Cyril), Methodius, Great Moravia, Christian ethics and morality

\section{Introduction}

In the history of Slavic peoples, Great Moravia played an immense role, especially in the second half of the $9^{\text {th }}$ century, having laid the grounds for their culture, literature and language. In the context of Great Moravia, such significant literary works of the period are mentioned as The Life of Constantine, The Life of Methodius, Foreword (Proglas), Judicial Law for laymen (Zakon sudnyj ljudem), Nomocanon (Nomokanon), Adhortation to Rulers (Vladykam zemle Božie slovo velit), and many others; moreover, literary, cultural, religious as well as legal documents of the given era have been interpreted (Avenarius, 1992, pp. 91-94; Betti, 2014, pp. 49-50, 75; Dvornik, 1956, pp. 84-85; Ivanov, 2008, pp. 316-318; Goldberg, 2006, p. 271; Jakobson, 1985, pp. 133-134; Kantor, 1983, p. 69; Kučera, 1986, pp. 171, 209; Mahoney, 2011, p. 26; Michalov, 2015, pp. 194-197; Pauliny, 1964, p. 81; Ratkoš, 1990, pp. 114-115; Sommer, Třeštík \& Žemlička, 2013, p. 249; Třeštík, 2001, pp. 205-206; Vašica, 2014, pp. 74-92; Vavř́nek, 1985, p. 232; Vavř́nek, 2013, pp. 203-207; Vlasto, 1970, pp. 59-66; Zozul'ak, 2019, pp. 13-21). The aim of the present paper is to analyse the nature of the literary works in question and study to what extent they are works of a moral nature and whether they can be considered to have laid the grounds of ethics, or Christian ethics, in Great Moravia.

\section{Nature of early Christian ethics}

In order to identify its features in the selected Great Moravian literary works, Christian ethics of the given period needs to be defined. Francine Cardman holds the opinion that theology, doctrine and Christian ethics of the period in question were not closed systems, only possible to be understood through their internal logic but should be perceived in a broader social, cultural and political context. She claims that early Christian ethics should not be studied exclusively by ethicists or, even, Christians, but a much broader community (Cardman, 2008, pp. 932-933). In her view, the development of early Christian ethics can only be observed indirectly by means of rituals, prayers, prophecies, etc. Early Christian ethics should be perceived as a Great area, i.e. all main components of religious history and historical theology are considered ethical resources dealing with such topics as war, peace, sexual morality, church order and discipline. Most preserved texts, regardless their authenticity, are related to the study of early Christian ethics. The same author points out that texts directly dealing with morality are rather rare. Only

\footnotetext{
${ }^{1}$ University of Prešov, Faculty of Arts, Institute of Ethics and Bioethics, Prešov (Slovakia); vasil.gluchman@unipo.sk
} 
a small number of them, if any at all, deal with theoretical reflections on ethics, albeit it secondarily (Cardman, 2008, p. 936).

Wayne A. Meeks also claims that should one, with regard to early Christianity, "[...] that when we speak of morality or ethics we are talking about people. Texts do not have an ethic; people do" (Meeks, 1993, p. 4). An effort to understand who these people were, what they did, what relationships they had, what they hoped for, and how they lived their lives is the essence of the study of early Christian ethics. It cannot be comprehended without understanding how a community works. In this author's view, Christian morality of the given period cannot be reduced to some theological or ethical documents. He holds that to study ethnography of the past means to search for the forms of culture and social practice that could be of importance for early Christian morality (Meeks, 1993, p. 11). He believes that to understand early Christian ethics, studying the moral directives created by early Christians (including their literary works) is of great importance (Meeks, 1993, pp. 66, 73). Eric Osborn also states that determining ideas in ethics are never only ethical, which can also be fully applied to early Christian texts (Osborn, 1976, p. 2).

Cardman considers the following as the main topics of early Christian ethics: the body including sexuality, asceticism and the care of the self, martyrdom and suffering. The topics of poverty, slavery, providence as well as history, religious intolerance and elites were also part of social ethics (Cardman, 2008, pp. 937-947). Henry Sidgwick claims that, in Christianity, the concept of morality as a positive law of a theocratic community is a novelty. In Christianity, the moralists' method determining the right conduct is, to a large extent, analogical to that used by lawyers when interpreting the codex. Holy commands were implicitly given for all life situations, or derived from the application of general rules included in the Holy Scripture. The moral view was defined as having knowledge of Divine law following an authority superior to human reason, which is only supposed to interpret the rules and apply them to more complex problems (Sidgwick, 1988, pp. 110-111). According to Sidgwick, faith is an inevitable precondition and essential motif of good Christian behaviour; however, adhering to the law and moral value of Christian duty depends on love. First and foremost is love towards God based on Christian faith, followed by love towards all those who are objects of God's love. This concerns derived Christian philanthropy regarding Christian pursuit of social duty (Sidgwick, 1988, p. 117).

Sidgwick further claims that, apart from faith and love, other important components of medieval Christian ethics were purity of heart, obedience, distancing oneself from the world and physical desires, patience, and charity. Purity of heart was not only understood with regard to sexual depravity, but was primarily connected to the entire sphere of morality. Another significant feature of the Christian understanding of morality as a code was unconditional submission, i.e. the virtue of obedience to authority, followed by a dismissive attitude towards the natural world and a devaluation of earthly social and civil relationships of the natural man, typical for the Roman pre-Christian world. Under the influence of Christianity, this was transformed into universal philanthropy, or related to a religious, or Christian, community. Part of it was the hate of one's body as a burden and obstacle in reaching the spiritual world. Originally, an integral part of Christian ethics and morality was the requirement to passively resist violence, which, however, gradually changed with the transforming status of Christianity in the Roman Empire (Sidgwick, 1988, pp. 118-121).

Sidgwick claims further values of Christian morality to be humility before God, which is the essential precondition of any true Christian good. The author also claims that the sphere of ethics was expanded by its interconnection with Revelational theology. The added religious power and sanctions proscribed the usual duties, related to religious faith and ceremonies, a moral dimension. In Christian ethics, the rightness of religious faith is viewed as essential for good and heresy as the gravest deadly vice destroying the sources of the Christian life. Sidgwick 
holds that Christianity created a legal concept of morality in the form of a code, whose breaking deserves supernatural punishment, as opposed to the philosophical perception of morality as a method of achieving natural happiness (Sidgwick, 1988, pp. 124-126). The development of church law in the Middle Ages was, according to him, probably an inevitable part of the great role of the Christian church in the effort to maintain a moral system in a highly anarchic period of the early Middle Ages (Sidgwick, 1988, p. 135).

\section{Early Christian morality in Great Moravia}

In the context of defining the scope of the topic in question it could be stated that individual features are valid for both early Christian philosophy and ethics and the period of the $9^{\text {th }}$ century, especially as far as Great Moravia is concerned, as the then society of Great Moravia was a true early Christian society. In these lands, Christianity had not long before been adopted (Bartoňková et al., 1966, pp. 341-342) which is why society and its elite did not yet fully identify with the new religion; a great number of the neighbouring countries and peoples did not adopt Christianity, or professed pre-Christian religions. Great Moravian society can, thus, be considered an early Christian society, although the adopted and spreading Christian teachings were more advanced since they had undergone some modifications passed by Christian councils. Still, the forms in which Christianity was presented to Great Moravian society primarily corresponded with the fundamentals of Christian teachings and morality and were to enhance its enrooting in the everyday lives of the faithful.

In the process of reasoning on the origins of ethics, or Christian ethics, in Great Moravia, it is vital to realise this does not concern the introduction of morality into the life of Great Moravian society. Should one accept the view which considers morality to be all that relates to a person's behaviour and actions, then it must be admitted that, even before the arrival of Constantine (Cyril) and Methodius as well as the first Christian missionaries from various parts of Europe, Great Moravian society had its own pagan, or pre-Christian, morality. Some of its features are known from period resources, such as descriptions by Arabic explorers who visited the lands inhabited by Slavic people or other authors (Bartoňková et al., 1969, pp. 343-348, 411-420). Descriptions of old Slavic people point out such characteristics as their promiscuous sexual morality, but also courage in military campaigns, etc. (Bartoňková et al., 1969, pp. 360$362,418)$. Slavs also held many pre-Christian religious rituals which included a great number of deities (Eliade, 1985, pp. 29-35; Rybakov, 1981; Slupecki, 1994, p. 7). This polytheistic religious system also involved certain moral requirements and rules which were preserved by tradition and passed on by word of mouth (Váňa, 1990). The adoption of Christianity and Christian morality by Slavic people followed some moral elements, customs and traditions of the previous period, which was also reflected in the more or less forced acceptance of preChristian customs and traditions which survived more than a thousand years and, in many cases, until the present day (Shrovetide, the drowning of Morena effigies, whipping and throwing water at girls at Easter, Pentecost, Midsummer Night bonfires, customs relating to St Lucia's day, etc.) (Nadaská, 2012; 2014).

Nevertheless, Christianity brought about new values, a new worldview for old Slavs and their everyday lives and relationships, and also, possibly, new view on what is right and wrong. The polytheistic Slavic system was replaced by a monotheistic Christian system with a single God, which, in many cases, required old Slavs to leave traditional modes of behaviour and actions behind, including promiscuity and polygamy, and adopt, together with a new faith, a new way of life. The need to enforce new values in newly Christian peoples and countries usually came from above, which means that the latter principle 'cuius regio, eius religio' (i.e. whose realm, his religion) was in force even back then. This meant that Christianity was primarily adopted by kings, princes and other representatives of the ruling strata who, consequently, Christianised the population of their lands. 
Christianity could only be enforced and spread in the turbulent Middle Ages by bringing about and enforcing new values (MacIntyre, 1998, p. 114). What was, however, vital was for the given values and norms of Christian ethics and morality to be maintained in the Christianised lands and communities. A highly efficient tool in the realisation of this intention was the Christian code of ethics (as Sidgwick also stated), which in a clear, simple and accurate way defined, or ordered, what was desirable and prohibited undesirable forms of behaviour and actions. The code also explicitly specified the norms of Christian ethics and morality and contained implicitly suggested Christian ethical values which formed the essence of the normative system of the ethical code.

The most appropriate form and means to achieve the goal was a law which was both binding for all and enforceable, also with the aid of the secular force, as it was actually this force that it was in service of, since it was the secular influence and the ruler's status and that of the social elite in a country that were to be strengthened. This is how a synergic effect came into being in medieval society, as by adopting Christianity and, especially, strengthening its influence (also with the aid, or support, of the Christian code of ethics), the internal political climate in the country and society became more stable, and the ruler and the elite were empowered. On the other hand, the status of Christian religion in society improved, which affected the Christian religion and the increasing ideological as well as power-related status of the Christian clergy in the country.

The most common form in which the Christian code of ethics was spread was a literary work expressed especially in legal regulations, since, in the Roman Empire, law had a long tradition and was an integral part of its life. The aim of the legal regulations was to define norms of Christian ethics and morality reflecting the values of Christian faith on the one hand, and the values of Christian ethics on the other. As Michael Thomas George Humphreys put it, Emperors Leo III and Constantine V in their Ecloga, for instance, tried to, by means of legal regulations, morally reform Byzantine society and its inhabitants, and to create a New Jerusalem and new Israelites. The aim of the Ecloga was to give rise to a new Christian society based on the teachings of Jesus Christ, which would pursue the values and norms of Christian ethics in the everyday life of society and its citizens (Humphreys, 2015, pp. 94-105; Freshfield, 1926). It was, presumably, the great goal set through the Ecloga by Emperors Leo III and Constantine V which inspired Constantine (Cyril) and Methodius to choose none other than this document as a starting point to set the values and norms of Christian ethics in order to, in this way, accomplish their task, or requirement, included in Rastislav's message to the Byzantine Emperor Michael III which, among other things, asked to give law to the Moravians (Kantor, 1983, p. 65).

\section{Forms of Christian ethics in Great Moravia}

During the rule of Rastislav (846-870), the mission of the Thessaloniki brothers gained univocal support from the state power; nevertheless, even then it encountered obstacles from Frankish missionaries operating in Great Moravian lands. I think that Constantine (Cyril) and Methodius viewed their mission as an opportunity to realise a grand goal also lying in the moral elevation and reform of Great Moravian society and its inhabitants; however, unlike the intellectually, culturally and literarily advanced Byzantine society, they came to a country whose culture was at a rather low developmental stage, including almost a complete lack of education. That is why it was, first of all, necessary to adapt the goals and expectations to real possibilities. In this way, translations of the literary works as The rules of the holy fathers (Zapovédi svatych otcov), Judicial law for laymen (Zakon sudnyj ljudem) and Nomocanon (Nomokanon) came into being, as well as the original literary work Adhortation to Rulers (Vladykam zemle Božie slovo velit) and many other original literary works and translations. 
Presumably, one of the oldest preserved literary works from the period of Great Moravia is The Rules of the Holy Fathers, which is a Church Slavonic translation of the original Latin penitential, i.e. an anthology of directives on repentance for various kinds of sins. ${ }^{2}$ Looking at sins and punishments included in this penitential, it is clear that contemporary Great Moravian society, or the church authorities, considered, in the context of the behaviour and actions of people living in Great Moravia in the given period, altering the most common forms of immoral actions an act of the highest importance. These included mortal dangers (murder, abortion), property offences (theft), sexual offences (fornication, adultery, bestiality), family offences (spousal abandonment, or divorce) and church offences (related to religious services).

Based on the punishments imposed it could be concluded that bestiality by a married priest was considered the worst sin, followed by sins for which a less strict penance was imposed, such as bestiality by an unmarried priest (15 years of penitence), premeditated murder, sodomy, adultery by a bishop, a priest leaving his own wife for another woman, and premeditated abortion as a consequence of adultery (all 10 years of penitence). More lenient punishments were administered for fornication by a priest, giving false oath, poisoning, arson and theft of church items (all 7 years of penitence); other penances were given for manslaughter, theft of livestock and other valuables, adultery by laymen and worshiping the Devil (all 5 years of penitence). Yet less strict, such as three year-long penances followed a minor theft, adultery by a priest, a mother killing her child, seduction of a female stranger, abortion, fornication with a widow or a virgin, or a priest hunting. Equally sinful was carolling (as pagans would) and being angry at one's brother, cursing him, or eating meat from a dead animal as well as acts related to the protection of altar bread from mice, dripping from the chalice during communion, sleeping in church (Bartoňková et al., 1971, pp. 138-146).

According to historians, the oldest Slavic legal literary work is Judicial law for laymen, which is, to a great extent, a translation of the Byzantine Ecloga. ${ }^{3}$ Judicial law for laymen deals with fighting paganism and also pays great attention to sexual morality, biological as well as spiritual marriage and kinship. A third of all the articles deal with issues of sexual ethics and morality (Bartoňková et al., 1971, pp. 181-186, 195-197). Other articles are concerned with the functioning of the judicial system in the country, morality in warfare, property matters, such as arson, theft, kidnapping and the sale of a free man for slavery (Bartoňková et al., 1971, pp. 187-194). From the above overview it is obvious how great an emphasis was placed on individual areas, which undoubtedly expressed the real needs of the functioning of Great Moravian society. It seems that the most serious problems both in Great Moravia and among its inhabitants were sexual morality and the need to protect marriage, which was, presumably, a serious issue in the given period in general not only in Great Moravia, as is documented in contemporary annals (Bartoňková et al., 1969, pp. 163-167, 171-172). Another serious problem of the period in question was theft, i.e. morality related to the protection of property.

\footnotetext{
${ }^{2}$ The above regulations in the Frankish area and also, presumably, in Great Moravia, were already in place before the arrival of Constantine (Cyril) and Methodius' Byzantine mission. The author of the translation is unknown and historians claim that the assumptions of Gorazd as the translator and St. Clement of Ochrid as the editor have not yet been proven. The Church Slavonic translation is merely a selection of original Latin regulations (Bartoňková et al., 1971, p. 137).

${ }^{3}$ In essence, it mainly concerns a translation of the Greek original of Ecloga a known code of laws by the Emperors Leo III and Constantine V. The code was issued in 726 and mainly included penal regulations. Historians point out several deviations of the Slavic translation from the Greek original, which, as they believe, means that this document reflects a different situation to that where the Ecloga originated. Nevertheless, Judicial Law for Laymen is an unsystematic and incomplete manual (Bartoňková et al., 1971, p. 147). Josef Vašica refuses the hypothesis of the document's Bulgarian origins and, in connection with the claims of similarity to Pope Nicholas I's responses to the Bulgarians and Judicial Law for Laymen states that the similarity is merely incidental (Vašica, 2014, p. 82). According to historians, Judicial Law for Laymen is a Great Moravian record and its author is most likely Constantine (Cyril) who could have been aided by Methodius as an experienced lawyer (Bartoňková et al., 1971, p. 176).
} 
Exceptional attention is also paid to the functioning of the judicial system in the country in order to centralise the enforcement of judicial power in an effort to eliminate arbitrary executions of justice, determine the rules of investigation and proving someone guilty or innocent. Last but not least, rules for the behaviour and actions of soldiers were also determined.

In the case of literary works, historians point out that these are not original works which came into being in Great Moravia, but mainly translations - selections from, as well as supplements to (or, in the case of punishments, amendments of originals), the original documents. Historians believe these were of particular significance and contributed greatly to the existential needs of Great Moravian society. Historians consider as a truly original Great Moravian literary work the sermon Adhortation to rulers ${ }^{4}$ which states that divine law commands rulers to love justice and do just deeds as the start of a journey to achieving a blessed life, which is why one needs to pay attention to what prevents them from achieving this goal and what should one absent from. In this sermon, equality before the law, or justice, is considered vital; the judge is not allowed to view anyone as better, and only pronounce the verdict of guilt and punishment after a careful investigation rather than superficial judgment of the whole argument. When dealing with a conflict, the judge is not allowed to side with his father, his mother, his child or friend; this is the only way to achieve true justice in the spirit of divine law (Bartoňková et al., 1971, pp. 199-200).

According to Adhortation to rulers, every prince should teach divine law to all his serfs and subordinates. Included in the requirements of divine law is not wronging the weak, avoiding pagan customs and oaths, respecting baptism and not marrying one's godparents or godchildren. In line with divine law, every man should be happy with his wife and not chase the pleasures of the flesh. He who breaks these laws and has been baptised, will be punished. It equally confirms the sanctity of marriage with the exception of such cases where the woman committed the sin of adultery. In the given context, Christ's word is mentioned saying that he who drove out his wife caused her adultery and he who shared the bed with her, also committed adultery, since two people joined by God shall not be separated. In a similar spirit, it is also stated that every man should have that woman who chose him according to divine law and that is how it should be regarded. Rulers are also warned and encouraged to maintain divine law not only by word but also by deed. They shall not, due to ignorance, moral flabbiness or physical love, assume that the requirements of divine law as well as the punishment for breaking it do not concern them. Sins and disobedience of divine law can also be punished by the loss of power, which, for instance, happened to the Jewish Old Testament King Saul, who disobeyed God. Adhortation to rulers also states that justice uplifts nations while sin and injustice lead people to decadence. On the other hand, the reward for those who are firm in their faith and maintain divine law lies in the hope of a blessed life in future (Bartoňková et al., 1971, pp. 201204).

Adhortation to rulers can be considered a contemporary analysis of the status of Christian ethics and morality, especially in the most fundamental areas of life of Great Moravian society, especially the enforcement of judicial power, marriage and behaviour and actions of the nobility. In the case of the nobility, it could even be assumed that instantiation of the regulations found within Judicial law for laymen is concerned in relation to magnates, which could be caused by squires approaching the norms of Christian ethics and morality, including the norms contained in these laws, in a rather relaxed manner; they marginalised them and did not take them seriously at all. As the fundamental principle of enforcing state power, Judicial law for laymen as well as Adhortation to rulers defined justice in all areas of social life, starting with an impartial approach to its execution, including investigating accusations. The author(s)

\footnotetext{
${ }^{4}$ According to historians, Adhortation to rulers is a sermon or warning to princes and rulers to maintain the divine law contained in Judicial Law for Laymen, from which, in their view, it follows that this is a Great Moravian literary record whose author was Methodius (Bartoňková et al., 1971, p. 199).
} 
view(s) justice as a guarantee of nations and countries flourishing; on the other hand, in injustice, they see the cause of decadence and, in the case of rulers, the loss of power.

Another important area that Adhortation to rulers pays attention to is marriage and its protection, as a consequence of enforcing the values, or norms, of Christian ethics and morality in the fight against paganism, its customs and traditions persisting within sexual morality. In the literary works in question, the fight against paganism is contained more implicitly than explicitly - it is mentioned rather rarely; however, the fight for consciousness or the souls of the inhabitants of Great Moravia is indirectly present in a vast majority of norms included in Judicial law for laymen.

Nomocanon, i.e. an almanac of church law, ${ }^{5}$ is yet another highly significant literary work from the Great Moravian lands, preserved from the period in question. Nomocanon paid most attention to church discipline and possible immoral behaviour and actions of persons holding clerical posts, starting with clerics, priests, and deacons all the way up to bishops. In many ways, Nomocanon paid great attention to the institution of marriage, also with regard to the clergy which, in the $9^{\text {th }}$ century, could, under certain circumstances, get married. It seems that in many cases the clergy suffered the same moral failures or, in other words, committed the same sins as laymen. If Methodius as the translator and compiler of Nomocanon (as well as the archbishop of Pannonia and Great Moravia) selected from among a great number of titles of the original document none other but these articles, it means he needed to strengthen the moral status of the clergy operating in Great Moravia (Bartoňková et al., 1971, pp. 250-259).

The second part of Nomocanon, which deals with formulating secular laws, contains certain peculiarities, since it does not place godliness above marriage and family, or the cohabitation of a man and a woman. In several cases, under the threat of punishment, casting out one's wife from the marriage under the pretence of godliness is disapproved of and so are other deeds for which godliness would be given as a reason, such as a woman having her haircut, wearing men's clothes, leaving her husband, etc. The disapproving attitude is justified by the opinion that the Lord created man and woman in the form He did; thus, anyone who should dispraise or refuse such phenomena actually dispraises God's work (Bartoňková et al., 1971, pp. 304-307). Heretics should be approached in a highly strict way and are placed at the same level as murderers. Such an attitude towards heretics is a reflection of the fight for the purity of the church and Christian teachings, since the early medieval church was involved in intense ideological as well as political battles against various interpretations of Christian teachings. That is why it was vital, albeit at the expense of strict punishments, to strengthen the status of the Christian church and the clergy in society; moreover, it was necessary to strengthen the Christian faith in society and its inhabitants. Similarly strict sanctions were imposed in the area of sorcery and all kinds of seers (Bartoňková et al., 1971, p. 333).

In this part, Nomocanon also pays attention to punishment for murder, premeditated abortion, adultery of lay men and women, abduction of girls with the intention of marrying them against their own will and/or the will of their parents and the upper class, which was strictly forbidden and punished. Similarly, bigamy in all its forms was forbidden and punished. In the same group of sins in the area of marriage and sexual ethics, or morality, is bestiality, which was punished most strictly of all human sins (25 years of penitence) (Bartoňková et al., 1971, pp. 334-347).

\footnotetext{
${ }^{5}$ Historians claim that the Moravian translation of the Nomocanon was not merely an interpretation of the Greek original Synagogy by St John the Scholastic, Patriarch of Constantinople (565-77), which included materials ranging as far as the Council of Chalcedon (451). In a sense, however, this was a new self-standing work (Bartoňková et al., 1971, p. 210). Methodius is considered the author of the translation, who, however, in a significant way, reduced the original extent of Scholastic's Synagogy. Cyril Vasil claims that the Moravian nomocanon only contains $37.5 \%$ of all canons in contrast to Synagogy by St John the Scholastic (Vasil', 2000 , p. 73). At the same time, he used the Syntagma structure of 14 titles, which is why, according to him, it would be appropriate to call this nomocanon Methodius'Syntagma (Vasil', 2000, p. 71).
} 


\section{Characteristics and assessment of Christian ethics in Great Moravia}

Nomocanon is the most complex legal and moral code from the times of Great Moravia, as it contains a summary of the most significant moral problems of the period and definitions of Christian ethical norms valid for basic areas regarding the civic activities of the inhabitants of Great Moravia. Nomocanon, together with Judicial law for laymen, The rules of the holy fathers and Adhortation to rulers formed the fundamentals of Christian ethics and morality in Great Moravia, which could be considered a highly significant outcome of Constantine (Cyril) and Methodius' Byzantine mission to Great Moravia. With regard to their activity among Moravians, the cultural and religious impact on the lives of Great Moravians is emphasised as well as their role in the creation of language, literature, and translation of works; however, no one has yet paid attention to the fact that, by translating original works from Greek into Church Slavonic, they formed the fundamentals of Christian ethics and morality in Great Moravia, as they determined norms of behaviour and actions of Christians, starting with laymen, clerics, priests, up to bishops, which also concerned the upper classes.

I think that just like Ecloga had the ambition to morally reform the Byzantine Empire and create a New Rome (Constantinople), the above Great Moravian literary writings had the same ambition, albeit without expressing it explicitly. Unlike Constantinople (or Byzantium), which was a culturally and religiously rather well developed powerful world centre, Great Moravia had only recently been Christianised and the status of Christianity among princes as well as the general population was presumably quite weak, a great number of pagan customs and traditions were kept and, possibly, pagan gods were worshiped, who were much more 'accommodating' and 'understanding' of the existing life of princes and common Moravians. Although direct moral imperatives are not expressed solidly in the existing statements contained in the literary works in question, in reality they are the core of all the documents, as it concerns a formalised explicit form of the norms of Christian ethics and morality and an implicitly formulated form of Christian moral values, which the norms in question follow. The above literary works can be considered the main ethical writings of the Great Moravia period.

The emphasis of the centralisation of the enforcement of judicial power and the refusal of individualised and subjective execution of punishment for unjust actions can be considered another highly significant aspect, especially in Judicial law for laymen. This involved a great strengthening of the state power in the country and a transition from a tribal to a feudal legal system where the power of individual tribal chiefs was replaced by a central power in the form of a single ruler or king. Here, monotheistic Christianity played a positive role, as a similarity between a single Christian God and a feudal ruler, or a monarch, arose, which replaced the previous polytheistic pagan system and a corresponding system of tribal chiefs. Centralisation of power, also with the aid of Christianity, enhanced the efficiency of the execution of power and its functioning at all levels, naturally within the given social, economic, political, ideological, cultural, religious, etc. environment. This also applied to the contemporary morality of medieval, including Great Moravian, society.

Should the characteristics of early, or medieval, Christian ethics be mentioned, as expressed by Cardman, Meeks, Osborn, and especially Sidgwick, it is also true with regard to Great Moravian society and its literary and ethical, or ethical-legal, writings, that they functioned as instructions of how to live well in the spirit of Christian ethics and morality. The basis of these teachings, values and norms differed from those of the ancient era, i.e. they followed the understanding of the Christian God as the highest good embodied by Jesus Christ as the model of behaviour and actions. In the period of Antiquity, the focus was on how to live well in the context of ancient society and realise the values required by society. In the case of Great Moravian society and its code of ethics, fulfilment of needs and requirements following social intentions was also concerned; however, this society had adopted the Christian faith and strived to implement its moral values in the everyday life of society and its inhabitants. 
In the Christian ethics known in Great Moravia, the primary focus was not on the development of the individual, but mainly the fulfilment of requirements related to the behaviour and actions of an individual with regard to society, or, more precisely, to God. These, for a believer, stemmed from Christian teachings, including Christian ethics and morality. From an autonomous moral agent in ancient times, a Christian individual becomes a heteronomous moral agent whose behaviour and actions are subjected to external requirements and his own development is merely a function in the fulfilment of social interests and needs on the one hand and, on the other hand, realising transcendental goals related to life after death, which was the main focus of medieval society and man.

The main literary and ethical writings in Great Moravia do not directly deal with the care of the self; this topic can be rather found as part of other documents, such as The Life of Constantine and The Life of Methodius. In these literary works, there are passages dealing with a description of Constantine (Cyril) and Methodius being forced to leave their hectic lives and enter monasteries, where, in the quiet, they contemplated on spiritual matters directed at religious elevation (Kantor, 1983, pp. 33, 41, 65, 109). Nevertheless, in the main literary and ethical works of Great Moravia, one can find indirect mentions of the care of the self via the emphasis on repentance, the need to regret one's sins, which is, however, presented as punishment rather than a positive programme for the formation and development of the Christian faith and morality.

All the above main literary and ethical writings are, to a great extent, influenced by the fact they formulate a Christian code of ethics in a negative way, i.e. as a set of prohibitions and punishment threats, which is partially connected to their legal character, as this resulted from the effort to increase their importance, as well as enforcement, in the life of Great Moravian society. Such character of the main literary and ethical documents, especially Judicial law for laymen, The rules of the holy fathers and Nomocanon was a reaction to the existing situation in Great Moravia, which means that it reflected the need to cope with the persisting customs and traditions in the behaviour of its inhabitants. Mircea Eliade calls these (in general) archetypal types of behaviour and actions found in almost all primitive, as well as in a great number of traditional, including pre-Christian, religions (Eliade, 1959, pp. 10, 27-29, 34-36).

From the overview of the main topics of early Christian ethics it follows that literary and ethical works of Great Moravia dealt with almost all main issues forming the core of not only early Christian ethics, but also medieval Christian ethics in general. Sexual ethics, including marriage, was paid greatest attention to in all main Great Moravian literary and ethical writings and concern was also extended to the topic of asceticism, since the issue of purity in various forms, especially sexual 'purity' in marriage as well as in relationships between men and women in general (including the purity of intentions) was also dealt with. Martyrdom and suffering is not directly included in the main literary and ethical works, it is rather found in The Life of Constantine and The Life of Methodius, where, by means of the stories of both Thessaloniki brothers, their suffering comes to the forefront, which is most significantly presented with regard to the fate of Methodius who was captured, imprisoned and tortured by Bavarian bishops (Kantor, 1983, pp. 119-127; Bartoňková et al., 1969, pp. 167-170). In this category also belong a great number of hardships that Constantine (Cyril) and Methodius had to face during their operations in Great Moravia caused by the Frankish clergy and its bishops, who stirred up a lot of intrigue and ill feeling with the intention of getting Methodius accused of heresy before the pope and prevent his further activity in Great Moravia and Pannonia (Bartoňková et al., 1967, p. 231).

Should one accept Cardman's classification of the topics dealt with by early Christian ethics into two areas, individual and social ethics (Cardman, 2008, pp. 932-956), then, it could be stated that literary and ethical Great Moravian works are even more complex than it would first seem, as they contain individual ethics (although it is not the focus) as well as social ethics. 
Individual ethics was covered above. As far as social ethics is concerned, for instance the topic of poverty, one can find solutions to theft-related problems (Bartoňková et al., 1971, pp. 138$146,192-194)$ although this could also be regarded as a negative programme, since no literary and ethical writing deals with how to resolve the problem of poverty, but attention is only paid to it when it comes to the surface and harms society or individuals and the thief is to be punished. This means that attention is only paid to the protection of property owned by an individual or society, including the church, but neither community nor the literary and ethical works in question dealt with poverty as such.

Much great focus goes to other pressing contemporary topics, especially the fight against heresies and heretics with the aim of supporting official explanations of Christian teachings adopted by Christian ecumenical councils. This also transpired in the fates of Constantine (Cyril) and Methodius who were, on several occasions, accused of heresy not only for using a Slavic liturgical language but also for conflicts present in the given period regarding the trinity teachings (filioque - i.e. deriving the origins of the Holy Spirit not only from the Holy Father but also His Son) (Bartoňková et al., 1967, p. 225), where both brothers held the view of the Byzantine church on refusing novelties which had been not approved by any council. According to preserved literary works, this conflict was officially the main reason for expelling Methodius' disciples from the Great Moravian lands, as they refused to acknowledge the practices of the western rite church, also strongly supported by the Frankish clergy (Bartoňková et al., 1967, p. 231).

Spiritual and secular elites were also a significant part of, especially, literary and ethical writings, as solving conflicts related to the behaviour and actions of Great Moravians often involved the clerical hierarchy, who strived to disengage from the authority of the secular upper class and took possession of the right to judge the secular upper class, which resulted in a great number of conflicts and, according to some authors, also (could have) contributed to king Svatopluk taking the side of the Frankish clergy in their conflict with Methodius' disciples. Apparently, the Frankish clergy was more lenient in judging the sins of the secular upper class, including Svatopluk's profligate life and polygamy (Bartoňková et al., 1967, p. 213). This may also have regarded the behaviour of other magnates, which was criticised by Methodius in his Adhortation to rulers (Bartoňková et al., 1971, pp. 199-204).

I think that in relation to the literary writings regarding the efforts of Constantine (Cyril) and Methodius' mission to introduce Christian values and norms into the Great Moravian social and moral life, it could be stated that it primarily concerned Christian social ethics, as the Christian community was the main object in the effort to pursue moral reform. All requirements for the behaviour and actions of an individual regard the interests and needs of the Christian community of which an individual Christian believer is a member. In the articles of Judicial law for laymen or the titles of Nomocanon, it is not an individual Christian and his life lived in accordance with the values and norms of Christian ethics that is the goal, but rather the needs and requirements of a Christian community which an individual is to respect and realise; i.e. to live a life which would be beneficial for the entire Christian community.

Since a primary recorded form of introducing the values and norms of Christian ethics in the social life of Great Moravia is concerned, attention is not really paid to more complex issues regarding the relationship between the earthly and celestial worlds. All requirements are primarily connected to the earthly world, i.e. solving moral problems in the everyday lives of the faithful with the end to increase the awareness of values and norms of the Christian faith and ethics. The process of adopting Christianity was often quick and superficial, sometimes even violent, without actual internal identification with the Christian faith and acceptance of its values and norms regarding the behaviour and actions of Christianised members of pagan nations and countries. 
In the context of the existing studies, I hold the opinion that, in Great Moravia, a Christian code of ethics came into being which, in the form of literary works, expresses the fundamental values and norms of Christian social ethics, which were supposed to regulate and direct the behaviour and actions of Great Moravians. From the above analysis of the literary writings in question originating in Great Moravia it could be concluded that one of the main matters of interest was the morality of Great Moravians. All literary works relevant from the viewpoint of state administration are, to a great extent, aimed at directing, or regulating, social, or interpersonal, relationships in the context of Christian ethical values. Even though they often came in the form of a clerical or secular law, in reality, it was a Christian code of ethics. At this point, it could be stated (also following Sidgwick) that this was a contemporary form of Christian ethics. Thus, it could be concluded that all the literary writings that have so far been presented as legal documents or files are actually ethical, or ethical-legal, documents, since it is ethics which forms their core and is their main content, even though they take the form of a clerical or secular law.

\section{Conclusion}

Based on the assessment and analysis of the presence of the main elements, or topics, of early Christian ethics, as Cardman and Sidgwick defined them, the existence of Christian ethics in Great Moravia can be confirmed in the sense of ethics dealing with morality, i.e. the behaviour and actions of people living in Great Moravia. In spite of the fact that none of the literary works includes the word 'ethical' or is a theoretical reflection or elaboration of a compact concept, in essence, a fairly well elaborated system with the existence of an essential Christian code of ethics (Judicial law for laymen) was formed, supplemented by further Christian ethical codes (The rules of the holy fathers and Nomocanon), and also takes the form of an analysis of its application to the life of Great Moravian society (Adhortation to rulers). Apart from these, there are also other literary works (The Life of Constantine and The Life of Methodius) which support the presented values and norms of Christian ethics included in the main ethical writings. I hold the view that, albeit in a reduced form, in the twenty years of Byzantine mission in Great Moravia, a rather complex model of Christian ethics came into being.

Constantine (Cyril) and Methodius can, thus, be indirectly considered the first ethicists of the given region during the existence of Great Moravia and their operations in this territory. It is true that they did not form an ethical system or write any philosophical or ethical works in spite of the fact that Constantine (Cyril) was called the 'Philosopher'. Their work can be, at best, regarded at the level of ethical and moral views of Constantine (Cyril) and Methodius, since, by the choice of works, their translations or completions (such as in the case of Judicial law for laymen) or their statements contained in Adhortation to rulers, they created the first ever version of a Christian ethical (or moral) code of ethics in Great Moravia, based on original works by missionaries, as well as Byzantine philosophical-ethical and legal traditions reflecting the needs of the era and its people. They truly significantly contributed to the development of Christian ethics and morality in the given region, which was followed by the literary works of their disciples in Bulgaria and, later, Kievan Rus', after they were expelled from Great Moravia. Their literary, philosophical, ethical and legal work later morphed into the form of Russian medieval codes of law, which decided the character of Christian morality and law in Russia till as late as the $16^{\text {th }}$ century. This is where the immense credit and significance of Constantine (Cyril) and Methodius' work for literature, philosophy, ethics and law lies.

\section{Acknowledgement}

The article is an output of the project KEGA 013PU-4/2019 History of ethical thinking in Slovakia II. 


\section{References}

AVENARIUS, A. (1992): Byzantská kultúra v slovanskom prostredí v VI.-XII. storočí [Byzantine culture in the Slavic environment in 6-12 th centuries]. Bratislava: Veda.

BARTOŇKOVÁ, D., HAVLÍK, L., MASAŘIIK, Z. \& VEČERKA, R. (eds.) (1966): Magnae Moraviae Fontes Historici I. Praha \& Brno: SPN.

BARTOŇKOVÁ, D., HAVLÍK, L., LUDVÍKOVSKÝ, J., MASAŘIIK, Z. \& VEČERKA, R. (eds.) (1967): Magnae Moraviae Fontes Historici II. Textus Biographici, Hagiographici, Liturgici. Praha \& Brno: SPN.

BARTOŇKOVÁ, D., HAVLÍK, L., HRBEK, I., LUDVÍKOVSKÝ, J. \& VEČERKA, R. (eds.) (1969): Magnae Moraviae Fontes Historici III. Diplomata, Epistolae, Textus Historici Varii. Praha \& Brno: SPN.

BARTOŇKOVÁ, D., HADERKA, K., HAVLÍK, L., LUDVÍKOVSKÝ, J., VAŠICA, J. \& VEČERKA, R. (eds.) (1971): Magnae Moraviae Fontes Historici IV. Leges - Textus Iuridici Supplementa. Prameny k dějinám Velké Moravy. Brno: UJEP.

BETTI, M. (2014): The making of Christian Moravia (858-882): Papal power and political reality. Leiden \& Boston: Brill.

CARDMAN, F. (2008): Early Christian ethics. In: S. A. Harvey \& D. G. Hunter (eds.): The Oxford handbook of Early Christian studies. Oxford: Oxford University Press, pp. 932-956.

DVORNIK, F. (1956): Slavs: Their early history and civilization. Boston: American Academy of Arts and Sciences.

ELIADE, M. (1959): Cosmos and history: The myth of the eternal return. New York: Harper Torchbooks.

ELIADE, M. (1985): History of religious ideas, vol. 3: From Muhammad to the age of reforms. Chicago \& London: The University of Chicago Press.

FRESHFIELD, E. H. (ed.) (1926): A manual of Roman Law the Ecloga published by the emperors Leo III and Constantine $V$ of Isauria at Constantinople A.D. 726. Cambridge: University Press.

GOLDBERG, E. J. (2006): Struggle for empire: Kingship and conflict under Louis the German, 817-876. Ithaca \& London: Cornell University Press.

HUMPHREYS, M. T. G. (2015): Law, power, and imperial ideology in the iconoclast era, c. 680-850. Oxford: Oxford University Press.

IVANOV, S. A. (2008): Religious missions. In: J. Shepard (ed.): The Cambridge history of the Byzantine Empire c. 500-1492. Cambridge: Cambridge University Press, pp. 305-332.

JAKOBSON, R. (1985): Selected writings, vol. VI: Early Slavic paths and crossroads, ed. \& preface S. Rudy. Berlin, New York \& Amsterdam: Mouton.

KANTOR, M. (ed.) (1983): Medieval Slavic lives of saints and princes. Ann Arbor, MI: The University of Michigan.

KUČERA, M. (1986): Postavy vel'komoravskej histórie [Characters of Great Moravian History]. Martin: Osveta.

MACINTYRE, A. (1998): A short history of ethics: A history of moral philosophy from the Homeric age to the twentieth century, $2^{\text {nd }}$ ed. London: Routledge.

MAHONEY, W. M. (2011): The History of the Czech Republic and Slovakia. Santa Barbara, CA: Greenwood.

MEEKS, W. A. (1993): The origin of Christian morality: The two first centuries. New Haven: Yale University Press.

MICHALOV, J. (2015): Národ a jeho učitelia. Dejiny kristianizácie Slovákov [The nation and its teachers: History of Christianization of Slovaks]. Bratislava: Herba.

NADASKÁ, K. (2012): Slovenský rok v l'udových zvykoch, obradoch a sviatkoch [Slovak year in folk customs, ceremonies and holidays]. Bratislava: Fortuna Libri. 
NADASKÁ, K. (2014): Čary a veštby: mágia v l’udovej kultúre Slovenska [Witchcraft and divinations: Magic in the folk culture of Slovakia]. Bratislava: Fortuna Libri.

OSBORN, E. (1976): Ethical patterns in Early Christian thought. Cambridge: Cambridge University Press.

PAULINY, P. (1964): Slovesnost' a kultúrny jazyk Vel'kej Moravy [Literary and cultural language of Great Moravia]. Bratislava: SVKL.

RATKOŠ, P. (1990): Slovensko v dobe vel'komoravskej [Slovakia in the Great Moravian era]. Košice: Východoslovenské vydavatel'stvo.

RYBAKOV, B. A. (1981): Yazytchestvo drevnich Slavjan [Paganism of the old Slavs]. Moskva: Nauka.

SIDGWICK, H. (1988): Outlines of the history of ethics. Indianapolis: Hackett.

SLUPECKI, L. P. (1994): Slavonic pagan sanctuaries. Warsaw: Institute of Archaeology and Ethnology.

SOMMER, P., TŘEŠTÍK, D. \& ŽEMLIČKA, J. (2013): Bohemia and Moravia. In: N. Berend (ed.): Christianization and the rise of Christian monarchy: Scandinavian, Central Europe and Rus, c. 900-1200. Cambridge: Cambridge University Press, pp. 214-262.

TŘEŠTÍK, D. (2001): Vznik Velké Moravy. Moravané, Čechové a střední Evropa v letech 791871 [Origin of Great Moravia: Moravians, Czechs and Central Europe in 791-871]. Praha: NLN.

VASIL, C. (2000): Kánonické pramene byzantsko-slovanskej katolíckej cirkvi v Mukačevskej a Prešovskej eparchii v porovnanís Kódexom kánonov východných cirkví [Canonical sources of the Byzantine-Slavic Catholic Church in the Diocese of Mukachevo and Prešov compared to the Code of Canonism of the Eastern Churches]. Trnava: Dobrá kniha.

VAŠICA, J. (2014): Literární památky epochy velkomoravské 863-885 [Literary relics of the Great Moravian epoch 863-885]. Praha: Vyšehrad.

VAVŘÍNEK, V. (1985): Historický význam byzantské misie na Velké Moravě [Historical importance of the Byzantine mission to Great Moravia]. In: J. Poulík \& B. Chropovský (eds.): Velká Morava a počátky československé státnosti [Great Moravia and the beginnings of Czechoslovak statehood]. Praha \& Bratislava: Academia \& Obzor, pp. 215-243.

VAVŘínEK, V. (2013): Cyril a Metoděj mezi Konstaninopoli a Římem [Cyril and Methodius between Constantinople and Rome]. Praha: Vyšehrad.

VÁŇA, Z. (1990): Svět slovanských bohů a démonů [The world of Slavic gods and demons]. Praha: Panorama.

VLASTO, A. P. (1970): The entry of the Slavs in the Christendom. Cambridge: Cambridge University Press.

ZOZULAK, J. (2019): Zdroj hodnôt v kultúrnom živote Slovanov [A source of values in the cultural life of the Slavs]. In: Konštantínove listy, 12(1), pp. 13-21. 